2017-09

\title{
An analysis of variable dissolution rates of sacrificial zinc anodes: a case study of the Hamble estuary, UK
}

\section{Rees, AB}

http://hdl.handle.net/10026.1/10025

\subsection{7/s11356-017-9762-2}

Environmental Science and Pollution Research

Springer Science and Business Media LLC

All content in PEARL is protected by copyright law. Author manuscripts are made available in accordance with publisher policies. Please cite only the published version using the details provided on the item record or document. In the absence of an open licence (e.g. Creative Commons), permissions for further reuse of content should be sought from the publisher or author. 
Accepted journal article in Environmental Science and Pollution Research - please refer to website

DOI: $10.1007 / \mathrm{s} 11356-017-9762-2$

Received 30 June 2017, Revised 8 September 2017, Accepted 11 September 2017, Available online 26 September 2017.

\section{- Acceptance date}

$11 \mathrm{Jul} 2017$

\section{Publication date}

Sep 2017

- Online publication date

25 Jul 2017

Embargo release date

25 Jul 2018

\section{Environmental Science and Pollution Research}

An analysis of variable dissolution rates of sacrificial zinc anodes: A case study of the Hamble estuary, UK --Manuscript Draft--

\begin{tabular}{|c|c|}
\hline Manuscript Number: & \\
\hline Full Title: & $\begin{array}{l}\text { An analysis of varial } \\
\text { Hamble estuary, UK }\end{array}$ \\
\hline Article Type: & Research Article \\
\hline Keywords: & Sacrificial anode, zir \\
\hline Corresponding Author: & $\begin{array}{l}\text { Aldous Rees } \\
\text { Southampton Solen } \\
\text { UNITED KINGDOM }\end{array}$ \\
\hline $\begin{array}{l}\text { Corresponding Author Secondary } \\
\text { Information: }\end{array}$ & \\
\hline Corresponding Author's Institution: & Southampton Solen \\
\hline $\begin{array}{l}\text { Corresponding Author's Secondary } \\
\text { Institution: }\end{array}$ & \\
\hline First Author: & Aldous Rees \\
\hline First Author Secondary Information: & \\
\hline Order of Authors: & Aldous Rees \\
\hline & Anthony Gallagher \\
\hline & Sean Comber \\
\hline & Laurie Wright \\
\hline
\end{tabular}

Order of Authors Secondary Information: 


\begin{tabular}{|c|c|c|}
\hline \multirow[t]{2}{*}{ Funding Information: } & International zinc Association & Mr Aldous Rees \\
\hline & Solent Protection Society & Mr Aldous Rees \\
\hline Abstract: & \multicolumn{2}{|c|}{$\begin{array}{l}\text { Sacrificial anodes are intrinsic to the protection of boats and marine structures by } \\
\text { preventing the corrosion of metals higher up the galvanic scale through their } \\
\text { preferential breakdown. The dissolution of anodes directly inputs component metals } \\
\text { into local receiving waters, with variable rates of dissolution evident in coastal and } \\
\text { estuarine environments. With recent changes to the Environmental Quality Standard } \\
\text { (EQS), the load for zinc in estuaries such as the Hamble, UK, which has a large } \\
\text { amount of recreational craft, now exceeds the zinc standard of } 7.9 \mu \mathrm{g} / \mathrm{l} \text {. A survey of } \\
\text { boat owners determined corrosion rates and estimated zinc loading at between } 6.95- \\
7.11 \mathrm{t} / \mathrm{yr} \text {. The research confirms the variable anode corrosion within the Hamble and } \\
\text { highlighted a lack of awareness of anode technology among boat owners. Monitoring } \\
\text { and investigation discounted metal structures and subterranean power cables as being } \\
\text { responsible for these variations but instead linked accelerated dissolution to marina } \\
\text { power supplies and estuarine salinity variations. }\end{array}$} \\
\hline \multirow[t]{2}{*}{ Suggested Reviewers: } & \multicolumn{2}{|c|}{$\begin{array}{l}\text { Marc Molinari } \\
\text { Southampton Solent University } \\
\text { marc.molinari@solent.ac.uk } \\
\text { Currently do work on corrosion issues at Southampton Solent. }\end{array}$} \\
\hline & \multicolumn{2}{|c|}{$\begin{array}{l}\text { Andrew Turner University of } \\
\text { Plymouth } \\
\text { andrew.turner@plymouth.ac.uk } \\
\text { Has knowledge on pollution sources from boats }\end{array}$} \\
\hline
\end{tabular}


David Johnson Seascape consultants

david.johnson@seascapeconsultants.co.uk

Opposed Reviewers:

Additional Information:

Question

Response

§Are you submitting to a Special Issue?

No 


\title{
An analysis of variable dissolution rates of sacrificial zinc anodes: A case study of the Hamble estuary, UK
}

Aldous B. Rees

School of Maritime Science and Engineering, Southampton Solent University, East Park Terrace, Southampton, SO14 0YN

Email: aldous.rees@solent.ac.uk

Tel:

Anthony Gallagher

School of Maritime Science and Engineering, Southampton Solent University, East Park Terrace, Southampton, SO14 0YN

Sean Comber

School of Geography, Earth and Environmental Sciences (Faculty of Science and Engineering), Plymouth University, Drake Circus, Plymouth, Devon, PL4 8AA

Laurence A. Wright

School of Maritime Science and Engineering, Southampton Solent University, East Park Terrace, Southampton, SO14 0YN

\begin{abstract}
Sacrificial anodes are intrinsic to the protection of boats and marine structures by preventing the corrosion of metals higher up the galvanic scale through their preferential breakdown. The dissolution of anodes directly inputs component metals into local receiving waters, with variable rates of dissolution evident in coastal and estuarine environments. With recent changes to the Environmental Quality Standard (EQS), the load for zinc in estuaries such as the Hamble, UK, which has a large amount of recreational craft, now exceeds the zinc standard of 7.9 $\mu \mathrm{g} / \mathrm{l}$. A survey of boat owners determined corrosion rates and estimated zinc loading at between 6.957.11t/yr. The research confirms the variable anode corrosion within the Hamble and highlighted a lack of awareness of anode technology among boat owners. Monitoring and investigation discounted metal structures and subterranean power cables as being responsible for these variations but instead linked accelerated dissolution to marina power supplies and estuarine salinity variations.
\end{abstract}

Keywords: Sacrificial anode, zinc, EQS, boats, Hamble, estuary

\section{Acknowledgements}

The authors would like to thank the former Hamble Harbour Masters David Evans and Wendy Stowe for their guidance and help with this survey and everyone else at the Harbour Board who have assisted especially Andy Melhuish and Alison Fowler. Thanks also go to all the boat owners on the Hamble who took the time to fill out the survey and the marinas and harbour masters who sent out the survey to their berth holders. Thanks also goes to Holly Pearson for her help and guidance with the use of the Voltammeter. This project is funded by The International Zinc Association, Hamble Harbour Board and Solent Protection Society. 


\section{Introduction}

Estuaries are an interface between terrestrial ecosystems and oceans; they are a vulnerable and dynamic environment often subject to wide tidal fluctuations and salinity ranges. Estuaries are also often home to large human populations, ports, marinas and industry (Matthiessen et al., 1999; Sámano et al., 2016). As such, they receive inputs of contaminants from a variety of sources, which need to be quantified and carefully managed to ensure compliance with Environmental Quality Standards (EQS) and the health of the ecology present.

The large amount of zinc released annually from anodes has the potential to contribute to estuaries exceeding the zinc EQS (Bird et al., 1996; Boxall et al., 2000). The new EQS for zinc in UK estuaries is $7.9 \mu \mathrm{g} / \mathrm{l}$ of total dissolved zinc, which includes a background level of 1.1 $\mu \mathrm{g} / \mathrm{l}$ and an EQS of $6.8 \mu \mathrm{g} / \mathrm{l}$ (Maycock et al, 2012), significantly reduced from the previous value of $40 \mu \mathrm{g} / \mathrm{l}$ for estuarine waters.

Studies have shown that zinc anodes on leisure craft can be a localised source of zinc to estuaries, which are capable of raising zinc levels in the vicinity of marinas and harbours, for example concentrations of $19.9 \mu \mathrm{g} / \mathrm{l}$ of total dissolved zinc were observed at Poole Harbour, which was significantly above control sites of $2 \mu \mathrm{g} / 1$ and the new EQS of 7.9 $\mathrm{g} / \mathrm{l}$. Similar concentrations were observed on the Hamble and Orwell estuaries (Bird et al., 1996: Boxall et al., 2000: Matthiessen et al., 1999). Studies on anode use and dissolution rates were also carried out in the Plymouth area by Wood (2014), Cathery, (2014) and Harrison (2015). Wood (2014) and Harrison (2015) found Plymouth marinas to have higher zinc concentrations in water and sediment samples, compared with nearby control sites. The alternative material to zinc anodes in the marine environment is aluminium (Mao et al, 2011). Aluminium anodes are used less frequently than zinc, mainly due to habits of boat owners and zinc being more commonly used in the past.

Sacrificial anodes are used to prevent corrosion on boat hulls; components on vessels such as propellers and other marine structures including wind turbines, pipelines and pontoons. This electrochemical process is known as cathodic protection (Young et al., 1979; Bird et al., 1996; DeGiorgi et al., 1998: Rousseau et al, 2009). Different elements are used for anodes depending on the ambient environmental conditions. Zinc anodes are most commonly used in seawater, aluminium anodes in seawater and brackish water and magnesium anodes in freshwater (MGDuff, 2016). It is recommended that zinc anodes comply with a US Army Standard (adopted worldwide) of $99 \%$ zinc with trace amounts of aluminium, cadmium and iron to make an alloy (Wagner et al., 1996). Aluminium and magnesium anodes have similar standards. To function correctly the anode metal has to be lower in the galvanic series than the metal it is protecting, metals lower in the series have a lower potential voltage (Rousseau et al, 2009). Aluminium anodes are not however as popular among boat owners as zinc anodes, this is thought to be due to tradition and habits of boat owners. It is estimated that there are approximately 382,000 marine leisure boats in the UK, many of which will replace anodes and antifouling paint annually (Comber et al., 2002; BMF et al, 2013). The Hamble estuary is home to approximately 3,000 leisure craft alone and is reported to be an area of high anode dissolution by boat owners.

For anodes to cathodically protect a boat or structure the anode has to be in direct contact with the item being protected or be connected by a wire (Rousseau et al., 2009; MGDuff, 2016). Anodes protect the cathode by forming an electrochemical cell. The flow of the electrons in this cell results in accelerated corrosion and 
dissolution of the anode and, in turn, a reduction in corrosion of the cathode (Genesca and Juares, 2000;

Rousseau et al., 2009). For this process to remain effective the corroded anode has to be replaced with a fresh anode. The interval of this replacement is generally considered a year, but depends on observed dissolution rates and individual boat owners preferences (Rousseau et al., 2009; Harris, 2008).

A number of reasons have been suggested for this varied anode dissolution rate by boat owners including stray electrical currents, salinity variations, $\mathrm{pH}$ of the estuary, current flow, the number of boats present, metal bridges and metal items in the estuary.

Anodes, however, are not the only source of zinc to estuaries. Estuaries with large human populations and boat numbers have the potential to exceed EQS standards due to zinc inputs from sources such as sewage effluent (Gardner et al., 2012), antifouling paints (Rees et al., 2014), road runoff (Rule et al., 2006; Comber et al., 2014), coastal and terrestrial landfill sites (O’Shea et al., 2014) and abandoned mines (Beane et al., 2016).

Within estuaries antifouling paints are also a source of zinc and copper to estuaries with some boats using zinc based paints such as zinc pyrithione, zineb, zinc acrylate copolymers or paints containing zinc additives and pigments (Young et al., 1979; Yebra et al., 2004; Rees et al., 2014; Turner et al., 2014). Zinc pigments often give a yellow colour or zinc oxide white (Abel, 1999). Boats are often abandoned in estuaries worldwide and these can continue to leach metals such as copper and zinc from paints and other metal items into estuaries (Rees et al., 2014; Turner and Rees, 2016). Many antifouling paints are copper based which raises copper concentrations in the vicinity of marinas, harbours and sediments surrounding abandoned boats (Comber et al., 2002; Rees et al., 2014; Briant et al., 2013).

This paper examines the perceived factors for a varied anode dissolution rate by boat owners (Fig 1), to determine if this is the case. This study utilises environmental monitoring data, questionnaire surveys and interviews with boat owners to examine their awareness surrounding anode use. Calculations to show zinc loads to the Hamble estuary from average corrosion rates were determined. The data collected from this research will help to quantify the significance of anodes as a source of zinc within the estuary, identify the factors controlling anode dissolution within the Hamble and beyond and to assist in suggesting mechanisms for future management of zinc in estuarine waters.

\section{Method}

\subsection{Survey of boat owners}

A self-administered questionnaire survey was designed and distributed to address the following questions; the types of sacrificial anodes being used; rate of anode replacement, awareness and knowledge of boat owners regarding anode use on the Hamble. Boat owners were also asked what antifouling paint they used to determine if they included zinc based paints. The anode survey was piloted by email to four boat owners; minor adjustments were made, before it was sent out. The survey was distributed via emails, emailed newsletters, twitter, and yachting forums. Boat owners within marinas (with electrical hook-up) and those without electrical supply in mid-channel were approached to determine if they observed different anode corrosion rates. Email 
yielded the greatest response rate, which along with discussions with boat owners and anode companies suggested reasons for varied anode dissolution rate and also areas of accelerated wear on the Hamble estuary.

\subsection{Anode corrosion rate calculation}

An anode corrosion rate ( $\mathrm{kg} / \mathrm{year} / \mathrm{vessel})$ was calculated for the Hamble from the survey data. The corrosion rate was calculated using the weight of each anode new and the percentage of the anode corroded after one year (the recommenced life for an anode). Where anodes were replaced at longer or shorter time intervals then the weight and percentages were calculated and normalised for a year. An average for the Hamble mid channel mooring berths and marina berths were then calculated (Tables 1 and 2). The corrosion rates were then multiplied by three as studies have found vessels average three anodes per vessel (Wood, 2014); this provided a corrosion rate per vessel rather than per anode

\subsection{Water sampling and analysis}

Water samples were collected in the Hamble estuary (mid channel and marinas) at a depth of 1.2 metres from the mouth, upstream, to the last moorings above Bursledon, in June and October 2015 and January 2016 (Fig 1). All equipment used for water sampling including, Ocean Test water sampler, LDPE bottles, filters and filter units were hydrochloric acid washed (10\% analytical grade $\mathrm{HCl})$ and washed copiously with ultra-high purity water (UHP, $18.2 \mathrm{M} \Omega$-cm). These samples were filtered through pre-acid washed $0.4 \mu \mathrm{m}$ polycarbonate filter membrane (Whatman Ltd) and analysed for their total dissolved zinc concentrations using cathodic stripping voltammetry (Pearson et al., 2016). Salinity measurements were also taken at each sampling site and salinity profiling on separate occasions at high and low tide to determine salinity extremes. .

The water samples were analysed using cathodic stripping voltammetry VA Computrace 797 (Metrohm). Total

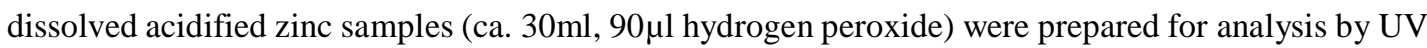
irradiation for 4 hours by a 400W medium pressure $\mathrm{Hg}$ lamp with Photochemical Reactors. 10ml aliquots of sample with a $100 \mu 1$ addition of a $238.3 \mu \mathrm{g} / \mathrm{l}$ concentration of 4-(2-hydroxyethyl)-1-piperazineethanesulfonic acid (HEPES) and a $25 \mu 1$ addition concentration of $164.3 \mathrm{~g} / 1$ ammonium pyrrolidine dithiocarbamate (APDC) were purged for 3 mins with $\mathrm{N}_{2}$ to degas the sample. Deposition times of 5-30 seconds were used depending on the zinc concentration present in the sample, at a potential of $-0.9 \mathrm{~V}$. Stripping was done by employing a sweep potential between $-1.2 \mathrm{~V}$ and $0.9 \mathrm{~V}$ (Pearson et al., 2016).

\subsection{XRF analyses of new zinc anodes}

A number of new zinc anodes were analysed for their metal content using a portable XRF (Niton XL 3T Gold Plus). The following parameters were used for the XRF, standard all metals, 180 second measurement time. One reading was taken from each anode in the majority of cases. Some of the anodes were from the same batch of anodes and were analysed to determine variations within anode quality. 


\section{Results and Discussion}

\subsection{Exceedance of EQS on the Hamble}

The Hamble estuary frequently exceeds the EQS of $7.9 \mu \mathrm{g} / \mathrm{l}$, with total dissolved zinc concentrations ranging between 3-31 $\mathrm{g} / \mathrm{l}$, with the majority of sites being between $5-20 \mu \mathrm{g} / \mathrm{l}$ across June and October 2015 and January 2016 (Fig 2). The EQS is based on an average concentration. The average across the three sampling sessions for the Hamble ranges between 4.14- $16.74 \mu \mathrm{g} / \mathrm{l} .10$ out of the 22 sampling sites fail the EQS based on average values, the majority of which are mid estuary samples (Fig 2). Higher zinc levels occur in the mid estuary due to high boat numbers in this section of the estuary, as well as a wastewater treatment works at Bursledon, anodes are however, likely to be the largest source of zinc to the Hamble estuary due to 3,000 being present (Fig 2). It is thought that most of the zinc from anodes is deposited into sediments, biota or flushed from estuaries (Matthiessen et al., 1999; Bird et al., 1996). There is however still sufficient concentrations within the water body of the estuary to raise levels above the EQS.

Studies in the Plymouth region, Poole Harbour, Orwell and Blackwater (Matthiessen et al., 1999; Boxall 2000; Wood 2014; Cathery, 2014; Harrison, 2015) have shown large amounts of zinc are released into other estuaries each year from anodes, estuaries with large boat numbers like the Hamble are likely to exceed the 7.9 $\mu \mathrm{g} / \mathrm{l}$ EQS due to increased zinc from anodes and sources such as wastewater treatment works (Maycock et al, 2012; Gardner et al., 2012). Wood (2014) found marinas in the Plymouth region had total dissolved zinc levels

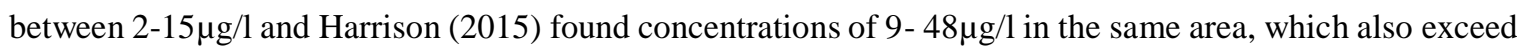
EQS. This was also observed by Bird (1996) and Boxall (2000) where marinas in some cases exceeded the EQS

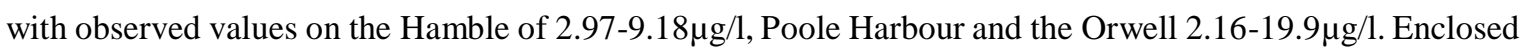
marinas with limited tidal flushing and therefore greater water residence times allowing a build-up of zinc in the water, were found to have higher zinc concentrations than open and semi enclosed marinas (Bird 1996; Boxall 2000; Wood 2014; Harrison 2015). Marinas on the Hamble tended to be open or semi enclosed, allowing regular and significantly more tidal flushing of the water. The zinc levels in the Hamble tend to be of the same magnitude as those reported in open and semi enclosed marinas within other estuaries. The marinas and mid channel tend to have similar zinc levels due to the large number of boats being moored in the channel and good tidal flushing of the marinas occurring.

Zinc anodes are not however the only source of zinc to estuaries such as the Hamble with contributions from the riverine section of the catchment, wastewater treatment works effluent and other sources such as road runoff and antifouling paints contributing to EQS levels not being met (Yebra et al., 2004; Rule et al., 2006; Rees et al., 2014; Gardner et al., 2012). Monitoring data, however, shows that riverine concentrations of total dissolved zinc are lower than those measured in the estuary (Fig 2), with 3.24 and $2.83 \mu \mathrm{g} / 1$ from two freshwater tributaries of the Hamble on Curbridge Stream. Concentrations of $4.68 \mu \mathrm{g} / 1$ at Curbridge and $1.51 \mu \mathrm{g} / \mathrm{l}$ at Botley were measured at the tidal limits of the Hamble's two tidal tributaries with a salinity of 5.44. This is considerably lower than values of $20 \mu \mathrm{g} / \mathrm{l}$ at Bursledon with salinities between 25 and 32 . The upper estuary is compliant with the EQS. The high salinities around Bursledon show the riverine input is limited. There are two sewage works on the tidal Hamble at Bursledon and downstream of Botley, other rural properties have their own septic tanks. 
The population of the Hamble is, however, low so inputs of zinc from sewage effluent discharged to the estuary is considered an insignificant source compared with anode inputs.

\subsection{Zinc anode corrosion rates and overall loads to the aquatic environment}

Using the calculated corrosion rates (Table 1) and average number of anodes per vessel (3) from the survey and the number of berths within each marina and mid channel moorings it was possible to calculate a total input of zinc to the aquatic environment from anodes (table 2). Boat owners suggested that marinas had a higher anode decay rate than mid channel moorings, hence a corrosion rate calculated for both. The mid channel and marina corrosion rate totals where added together to give an overall Hamble zinc load.

Table 1 Zinc anode release rate per vessel

\begin{tabular}{|cccc|}
\hline Release rate location & Berths & $\begin{array}{l}\text { Corrosion rate } \\
\text { (kg/yr/vessel) }(3 \text { anodes })\end{array}$ & $\begin{array}{l}\text { Load to } \\
\text { estuary (t/yr) }\end{array}$ \\
\hline Hamble Mid channel (MC) & 600 & 1.62 & 0.97 \\
Hamble Marina & 2400 & 2.49 & 5.98 \\
Hamble (Boxall et al., 2000) & 3000 & 2.37 & 7.11 \\
\hline
\end{tabular}

The zinc load calculated for mid channel moorings was 0.97t/yr and marinas 5.98t/yr which in total was 6.95t/yr (Table 2). Boxall et al., (2000) also calculated a zinc release rate for the Hamble of $2.37 \mathrm{~kg} / \mathrm{yr}$ for 3 anodes which gave a zinc load of 7.11t/yr. This was calculated for the Hamble as a whole and not mid channel and marinas moorings being separate. This study and Boxall et al., (2000) gave similar zinc corrosion rates' for the Hamble. This shows the high levels of zinc released into the Hamble estuary each year from anodes, which indicates why anodes are the biggest source of zinc to the Hamble. This leads to the EQS not being met. Inputs from individual marinas ranged between 0.12t/yr at RK marine to 0.90t/yr at Mercury Marina (Table 2). Individual vessels in marinas and moorings accounted for between $0.02-0.90 \mathrm{t} / \mathrm{yr}$ of zinc to the Hamble.

Table 2 Hamble zinc load calculations from anode release rates

\begin{tabular}{|lccc|}
\hline \multicolumn{2}{|c|}{ Corrosion rate (kg/yr/vessel) } & $\mathbf{1 . 6 2}$ & $\mathbf{2 . 4 9}$ \\
\hline Hamble estuary moorings & Berths & Zinc load (t/yr) \\
\hline Mid Channel & 600 & 0.97 & \\
Hamble Point Marina & 230 & & 0.57 \\
Harbour Board Mooring & 10 & 0.02 \\
Royal Southern Yacht Club & 110 & 0.27 \\
Port Hamble & 340 & 0.85 \\
Mercury Marina & 360 & 0.90 \\
Universal Marina & 250 & 0.62 \\
Stone Pier Yard & 67 & & 0.17 \\
Elephant Boatyard & 70 & & 0.17 \\
Swanwick Marina & 330 & 0.82 \\
Deacons Marina & 160 & 0.40 \\
Cabin boatyard & 73 & & 0.18 \\
Riverside boatyard & 100 & 0.25 \\
RK Marine & 50 & 0.12 \\
Foulkes Boatyard & 180 & 0.45 \\
Eastland's Boatyard & 70 & 0.12 \\
\hline
\end{tabular}




\begin{tabular}{|lcc|}
\hline Total & 0.97 & 5.98 \\
Hamble Total & \multicolumn{2}{c|}{6.95} \\
\hline
\end{tabular}

Corrosion rates of $1.2,1.35$ and $0.81 \mathrm{~kg} / \mathrm{yr} / \mathrm{vessel}$ were calculated by studies in the Plymouth area by Wood, (2014), Cathery, (2014) and Harrison (2015), these gave zinc loads ranging between $1.33-2.33 t / y r$ for the 1654 vessels in the Plymouth marinas. Corrosion rates from Plymouth marinas were either calculated through a survey (Wood, 2014) or estimates form the MAM-PEC model (Cathery, 2014; Harrison, 2015). This was lower than the Hamble due to lower release rates and boat numbers in Plymouth marinas.

The Orwell and Blackwater estuaries have 1919 and 1860 vessels respectively making them most similar in vessel numbers to the Hamble and Plymouth. Using Corrosion rates of $0.87 \mathrm{~kg} / \mathrm{yr}$ and $2.37 \mathrm{~kg} / \mathrm{yr}$ from Matthiessen et al., (1999) and Boxall et al., (2000) respectively and for an average of three anode per vessel, anodes release between 1.66-4.54t/yr on the Orwell estuary and 1.61t/yr for the Blackwater estuary. Total dissolved zinc levels at Fullbridge on the Blackwater an area of high boat density had an average of $15.23 \mu \mathrm{g} / \mathrm{l}$ in 2015 (Environment Agency, 2016). Total dissolved zinc on the Orwell downstream of Wolverstone marina and Pin Mill was 9.51 $\mu \mathrm{g} / 1$ (Environment Agency, 2016). The Plymouth area and the Blackwater and Orwell estuaries like the Hamble show the large amount of zinc released annually from anodes, which can contribute to EQS levels not being met in estuaries generally.

Matthiessen et al., (1999) used the zinc corrosion rate equation (equation 1) to estimate zinc loads from anodes into Suffolk and Essex estuaries (Stour, Orwell, Crouch, Roach and Blackwater), with the assumption of one anode present per vessel instead of an average of three used in this study. Individual docks accounted for an estimated zinc range of $60-540 \mathrm{~kg} / \mathrm{yr}$ and marinas and moorings a range of $0.29-320 \mathrm{~kg} / \mathrm{yr}$. Felixstowe Docks which is a large container port was the largest source of zinc in the area (Matthiessen et al., 1999).

\subsection{Questionnaire results and anode replacement rates}

Seventy three survey responses where received from the Hamble boat owners, mid channel mooring holders accounted for 58 responses and marinas 15. The survey indicated a number of issues such as the lack of awareness among some boat owners about the use of anodes. In some cases anodes containing inappropriate metals were used; with magnesium used in seawater in two cases on the Hamble. The magnesium will effervesce and quickly corrode in a seawater environment, which has the potential to cause detrimental corrosion to the boat (MGDuff, 2016).

Questionnaire responses show that 59\% of boat owners replace their anodes annually on the Hamble (Fig 3). The overall mean replacement for marinas is slightly higher than the moorings mid channel (1.3 compared with 1.2 years respectively, based on the assumption that replacement is at the midpoint of the survey response - i.e. $<1$ year $=6$ months, $>1$ to $>2$ years $=1.5$ years, etc.) (Fig 4). A t-test was conducted to compare frequency of anode replacement between mid channel $(\mathrm{M}=1.19, \mathrm{SD}=0.47)$ and marina moorings $(\mathrm{M}=1,28, \mathrm{SD}=0.89)$, which indicated no significant difference in replacement frequency $(\mathrm{t}(72)=0.40 \mathrm{p}>0.05)$. Although anodes lasting much beyond a year indicate they may not be bonded correctly or are in effective at preventing corrosion. In some cases boat owners specified they did not know why they used anodes, this was the case in 
some of the marinas with long replacement times, which increases the average replacement for marinas, as indicated by the following quotes from boat owners on the Hamble“...mine seem to erode very slowly, I changed them this year more out of guilt then needing to..." and "To be honest, I don't really know what they are for and I don't think they are of any significance for me". This implies a lack of knowledge and awareness among boat owners regarding anode replacement and dissolution mechanisms. The corrosion rates from this study indicates that zinc anodes corrode quicker in marinas compared with mid channel moorings, with the Hamble mid channel corrosion rate of $1.62 \mathrm{~kg} / \mathrm{yr}$ being lower than the Hamble marinas release rate $2.49 \mathrm{~kg} / \mathrm{yr}$, this is not, however, supported by the replacement rate (Fig 3). This could be due to the number of marina responses and some of the marina questionnaire replies noting anode replacement at relatively large timescales (longer than deemed the norm by the boating community). Boat owners, however, have noticed marinas generally do corrode quicker than mid channel moorings "There is definitely an increase in degradation when in marinas and when on extended periods of shore power. Much less on the mid river moorings" and "Keeping a boat away from marinas is helpful as there are too many stray electrical currents that can eat away anodes and props".

From survey responses on the Hamble, boats had an average of three anodes, mainly attached to the propeller shaft and hull, a few vessels had as many as 10 to 15 anodes, however. An average of three anodes per boat was also found in marinas within the Plymouth area by Wood (2014). There was a general trend of larger vessels having greater anode numbers, but some vessels had as many as 8 - 10 anodes at 6 metres as well as up to 14 metres (Fig 5). The boat owners with more anodes on smaller vessels had generally experienced corrosion issues so used more anodes. This once again suggest a lack of knowledge and awareness as more anodes on the same metal item will protect it better than one, placed correctly. High anode corrosion rates suggest a possible fault with boat wiring or the wrong size anode being used on the vessel (Harris, 2008).

There are few other datasets with which to compare these values for the Hamble, however a similar questionnaire survey was undertaken by Wood (2014) on 40 boat owners from Sutton Harbour and Queens Anne Battery in Plymouth. These are high salinity (typically >30) shore side purpose built marinas, with Sutton Harbour having a lock gate to retain water. Based on boat owner responses anode replacment rates were slightly less frequent than in the Hamble (mean 1.7 years). The Plymouth survey suggested the use of shore power accelerated anode wear, just like it did on the Hamble (Wood, 2014). This suggests that there is not just accelerated wear in the Hamble, but what boat owners on the Hamble deem as acclerated wear within marinas with electrical hook ups is further geogrpahically spread than just on the Hamble. Electrical hook ups are not present at mid channel sites so are not an issue.

Time in the marina or at mooring showed no strong relationship with anode replacment frequency in marina locations on the Hamble. Vessels tend to stay in marinas or at moorings year round and are only coming out of the water for maintenance which often includes anode replacment and having antifouling paint re-applied (Fig 6). This maintenace work is normally only a matter of weeks and is generally in the winter months. The number of vessels out of the water at anyone time is minimal compared with the total numbers present on the Hamble. 


\subsection{Possible factors controlling anode corrosion rates}

The survey indicated that knowledge and awareness surrounding anodes among some boat owners is limited. The science behind cathodic protection is complicated, so in a bid to explain and understand it, non-scientific theories have been suggested. Many of these theories appear plausible but chemically are not possible, these theories spread through hearsay rather than fact. The idea that metal objects in the river and the metal railway bridge seem plausible, as anodes would cathodically protect many of these items. However as boats are not physically connected to these items an electrical cell will not be formed, meaning anodes cannot corrode via this source (Rousseau et al., 2009; Wagner et al., 1996). This therefore means metal debris, D-Day shell cartridges, scrap aluminium possible thrown in the river from the Fairey Aircraft factory, mooring debris in the estuary and the railway bridge, all suggested by boat owners as reasons, will not effect and cause variation in anode dissolution rates. They could however increase metal levels within sediments and the water column of the Hamble, which in turn will impact on compliance with the EQS.

Variations in salinity are likely to be one of the main factor controlling anode corrosion rates. Low salinity waters causes a calcareous build up on the anode which effects the rate and ability of corrosion (Rousseau et al., 2009; Caplat et al., 2010). Zinc anodes are created from an alloy (Table 3), which allows a steady rate of corrosion in marine waters, this is a US Military Standard. These standards are created for seawater conditions, which means they are less effective in brackish waters and zinc anodes do not corrode in freshwater, due to a layer of zinc hydroxide $\left(\mathrm{Zn}(\mathrm{OH})_{2}\right)$ forming on the anode, this will form to a lesser extent in brackish waters (Wagner et al., 1996; Gavrila et al., 2000; Jelmert and Van Leeuwen, 2000; Harris, 2008). Freshwater is 10 times less conductive than seawater, zinc $(-0.98$ to $-1.03 \mathrm{~V})$ corrodes at a higher voltage than magnesium $(-1.60$ to $-1.63 \mathrm{~V}$ ) so is better suited to seawater (Morgan, 1987). If zinc anodes are removed from water they coat over with a layer of zinc hydroxide and calcium which prevents corrosion, this can occur if boats moorings dry out at low water (Gavrila et al., 2000) (Fig 7). Most boats which have indicated a varied and accelerated dissolution rate are moored at Bursledon or upstream of Bursledon on the Hamble estuary. The salinity in this area ranges between 17and 31, but can be as low as 5 at low water in extreme conditions (Environment Agency, 2016) (Data collected during this study). The salinity range that occurs in this area is likely to be a reason for the suggested accelerated wear. Yachting forums and discussions with boat owners indicated areas of accelerated corrosion also occurred beyond the Hamble, with marinas on the in the Solent, river Orwell in Suffolk and Chatham marina in Kent being suggested. Salinity and stray currents have been suggested as reasons like on the Hamble. The Orwell estuary below Ipswich Docks had a salinity range of 23.36 - 32.64 during 2015 (Environment Agency, 2016), which is similar to the Hamble estuary. Salinity on the Orwell reached as high as 34 at Shotley (Environment Agency, 2016).

Stray currents is a term often referred to by boat owners as a reason for a varied anode dissolution rates, stray currents in the marine industry are referred to as the portion of current that flows over a path other than the intended path (ACE Group, 2014). Stray current corrosion is where an outside power source flows into the vessels metal components and out through the water as a ground (Fig 8) (Corrosionpedia, 2015). These stray currents can be Direct Currents (DC) which generally cause corrosion to boat fittings and anodes, and Alternating Current (AC) which introduces high voltage current to area surrounding boats, which can result in death, but does not cause corrosion to vessel, this should not occur due to earthing and isolating of these currents 
at power supplies (ACE Group, 2014). When boat owners refer to stray currents they are referring to DC stray currents. Many marinas provide electrical hook ups powering lighting, power points and cookers on modern boats, these power supplies are AC currents. There are two main types of DC stray currents, external sources to the vessel from marina power supplies and other vessels using the same power supply and internal sources which could be an incorrectly wired appliance or an electrical accessory, anodes act as an earth for static electricity for these appliances, through the engine negative terminal which in turn is connected to the anode (Newboatbuilders, 2015). The boat with the weaker earthing system is most likely to be affected, this could be due to the quality of the wiring, the earthing style, or type of electrical equipment on board. Many boats are wired by boat owners, or terrestrial electricians instead of marine ones, this can lead to grounding and fusing issues due to boat wiring requiring different techniques to terrestrial electrics. Boats in marinas are connected to power supplies and each other and the pontoon through a common earth wire, which allows these stray currents to effect more than one vessel. This can lead to corrosion on a vessel, if it has no anodes, the anodes are not connected correctly or not all metal items are protected by anodes. If the next boat is leaking a DC current the neighbouring boat can act as the DC ground through the marina power supply if both connected to this power source and the other vessel provides the path of least resistance to the ground (Newboatbuilders, 2015; Corrosionpedia, 2015).

A galvanic isolator can be used to break the circuit between vessels, this acts as a filter, blocking the flow of low voltage galvanic (DC) currents but at the same time maintaining the integrity of the earthing circuit (BoatU.S, 2016). About 50\% of respondents had these on their vessels moored in marinas and mid channel. Boat owners with these did not however note lower corrosion rates "I still get some electrolytic corrosion on rear propeller when operating fridge on shore power despite the galvanic isolator". Galvanic isolators generally do not prevent corrosion and are not designed to, but they will limit it and stop catastrophic corrosion issues if an electric fault occurs, by breaking the two way flow of currents which are a common source of stray currents. Using power supplies only when on board, will also reduce anode corrosion, as vessels are less liable to stray currents without power supplies. It is common for many vessels to be continually plugged into power supplies to maintain battery power, etc. It has also been suggested that some marinas pontoons are not cathodically protected themselves, protection to the pontoon structure is therefore provided by the anodes present on the vessels through the earth wire of the power supplies. A galvanic isolator will also prevent this as allows only one way current flow.

It is likely that anode corrosion is accelerated by stray currents in marinas beyond the Hamble. The Yachting forums indicate this to be the case in many other marinas such as Chatham in Kent and at Wolverstone Marina on the Orwell estuary. This is shown through the following posts: "Just wondering if any berth holders at MDL Chatham maritime, have experienced any unusual corrosion levels either galvanic or leakage / stray currents from other boats. Shore power etc?" and "I have heard a few knowledgeable people discussing the electrolysis at Chatham. It's a bit of an issue apparently".

It has been suggested that subterranean power cables under the Hamble (and other estuaries) cause varying anode dissolution rates, this was suggested by two respondents of the survey on the Hamble. These would be protected and earthed so will not release any stray current, as would short out if this was not the case. The 
electrical supply for the railway bridge which has also been suggested as source, this will be isolated and is not connected to the vessels in anyway. This therefore means these will not cause variations in anode corrosion.

XRF analyses on the surface of new anodes was carried out to determine the metal content and to see if anodes meet the US Military standards for anodes (Wagner et al., 1996; Harris, 2008; BoatU.S, 2016). The tests showed that the metal content of anodes in a single batch showed considerable variation and many of these anodes had more metals in then they were meant to. The US Specifications specify that metals not mentioned in the standard should not exceed $0.1 \%$ many of these do, with some anodes having as much as $1.1 \%$ (Table 3 ) (Wagner et al., 1996; BoatU.S, 2016). Zinc levels ranged from 96.4 to $98.3 \%$, so all were slightly under the $99.3 \%$ standard. It is also thought that some cheaper manufacturer's anodes generally do not meet these standards. The majority of anodes had only one XRF replicate, but a couple of anodes did have three and these showed very little variation in metal content (Table 4). The US standard is meant to be the best alloy for saltwater environment (Wagner et al., 1996), it is not, however, clear how much these differences will alter anode dissolution. Alloys have been adapted and changed over time (Morgan, 1987), further tests on anodes with different alloy compositions would be needed to test if the variations in anode composition have an effect on the Hamble.

Table 3 XRF analyse of new anodes to indicate metal content present

\begin{tabular}{|c|c|c|c|c|c|c|c|c|c|c|c|c|}
\hline $\begin{array}{c}\text { Element } \\
\%\end{array}$ & $\begin{array}{l}\text { Zn anode } \\
\text { standard }\end{array}$ & $\begin{array}{l}\text { Bar } \\
\text { anode 1 }\end{array}$ & $\begin{array}{l}\text { Bar } \\
\text { anode 2 }\end{array}$ & $\begin{array}{l}\text { Bar } \\
\text { anode } 3\end{array}$ & $\begin{array}{l}\text { Hanging } \\
\text { anode } 1\end{array}$ & $\begin{array}{l}\text { Hanging } \\
\text { anode } 2\end{array}$ & $\begin{array}{l}\text { Hanging } \\
\text { anode } 3\end{array}$ & $\begin{array}{l}\text { Hanging } \\
\text { anode } 4\end{array}$ & $\begin{array}{l}\text { Hanging } \\
\text { anode } 5\end{array}$ & $\begin{array}{l}\text { Hanging } \\
\text { anode } 6\end{array}$ & $\begin{array}{l}\text { Hull } \\
\text { anode 1 }\end{array}$ & $\begin{array}{l}\text { Hull } \\
\text { anode } 2\end{array}$ \\
\hline $\mathrm{Zn}$ & 99.32 & 98.27 & 98.03 & 97.01 & 97.32 & 98.24 & 98.24 & 96.98 & 97.41 & 96.4 & 97.36 & 96.74 \\
\hline $\mathrm{Al}$ & $0.1-0.5$ & & 0.64 & 0.63 & 1.14 & 1.32 & 0.87 & 1.08 & 1.01 & 1.5 & 0.94 & 0.97 \\
\hline V & & & & & & 0.03 & & 0.03 & & 0.02 & 0.06 & 0.11 \\
\hline $\mathrm{Cd}$ & 0.07 & 0.04 & 0.04 & 0.04 & 0.04 & 0.37 & 0.03 & 0.02 & 0.04 & 0.04 & 0.03 & 0.03 \\
\hline W & & & & & & & & & & 1.11 & & 0.83 \\
\hline $\mathrm{Cu}$ & & 0.02 & & & & & & & & & & \\
\hline $\mathrm{Fe}$ & 0.01 & 0.01 & 0.02 & 0.03 & 0.03 & 0.02 & 0.02 & 0.05 & 0.04 & 0.05 & & \\
\hline $\mathrm{P}$ & & & & & & & & 0.12 & & & & \\
\hline \multicolumn{13}{|l|}{$\mathrm{Ti}$} \\
\hline $\mathrm{Zr}$ & & & & & & & & 0.06 & & & & \\
\hline $\begin{array}{l}\text { Other/oth } \\
\text { er total }\end{array}$ & 0.01 & 0.02 & & & & 0.88 & 0.05 & 0.26 & 0.05 & 1.13 & 0.06 & 1.11 \\
\hline
\end{tabular}


Table 4 XRF analyses reps of a hull anode, to show little variation in most elements within an anode

\begin{tabular}{|ccccc|}
\hline Element \% & $\begin{array}{c}\text { Zn anode } \\
\text { standard }\end{array}$ & $\begin{array}{c}\text { 4kg Hull } \\
\text { anode } \\
\text { R1 }\end{array}$ & $\begin{array}{c}\text { 4kg Hull } \\
\text { anode } \\
\text { R2 }\end{array}$ & $\begin{array}{c}\text { 4kg Hull } \\
\text { anode } \\
\text { R3 }\end{array}$ \\
\hline $\mathrm{Zn}$ & 99.32 & 96.6 & 95.74 & 96.84 \\
$\mathrm{Si}$ & $0.07-0.025$ & 1.88 & 1.04 & 0.89 \\
$\mathrm{Al}$ & $0.1-0.5$ & 1.59 & 2.96 & 1.23 \\
$\mathrm{~V}$ & & & 0.02 & 0.05 \\
$\mathrm{Cd}$ & 0.07 & 0.04 & 0.1 & 0.04 \\
$\mathrm{Cr}$ & & & & 0.05 \\
$\mathrm{~W}$ & & 0.03 & 0.18 & 0.10 \\
$\mathrm{Cu}$ & & & \\
$\mathrm{Fe}$ & 0.01 & 0.01 & & \\
$\mathrm{P}$ & & & & \\
$\mathrm{Ti}$ & & & & \\
$\mathrm{Zr}$ & & & \\
$\mathrm{Pb}$ & & & & \\
Other/other & 0.01 & & & \\
total & & & & \\
\hline
\end{tabular}

$\mathrm{PH}$ has also been suggested as a possible reason, the $\mathrm{pH}$ in the Hamble is generally around 8 and does not significantly vary. It is very similar to many other estuaries so is unlikely to be a cause of accelerated corrosion. Fast water flow was also suggested by boat owners on the Hamble. Anodes need some water movement to prevent a calcareous and $\mathrm{Zn}(\mathrm{OH})_{2}$ build upon them (Rousseau et al, 2009), it is however unlikely fast flowing water will cause greater anode corrosion.

Aluminium could be an alternative for some brackish conditions in the upper reaches of the Hamble, as can be used in brackish and seawater (Harris, 2008; MGDuff, 2016), parts of the Hamble varies from brackish to seawater with changes in river flow, tidal conditions and rainfall. Aluminium is considered less of an environmental concern regarding potential toxicity than zinc in marine waters and currently has no EQS set (Harris, 2008: Mao et al, 2011; Gabelle et al., 2012). This indicates that aluminium could be more suited to these areas, as it is of causes less environmental concern and could reduce anode dissolution rates in these areas. The survey and discussions with boats owners indicated that only a small percentage were, however, using aluminium anodes, with only two respondents using. This is partly due to zinc being more commonly used in the past and zinc being recommended over aluminium by anode manufacturers and suppliers in high to mid salinity regions. If aluminium anodes became more commonly used this could reduce zinc levels to below EQS. Aluminium anodes are relatively widely used on marine structures such as wind farms and larger vessels, so can become more widely used on pleasure craft (Gabelle et al., 2012).

A number of boat owners who completed the survey did not have anodes present on vessels. In some cases this was due to lack of knowledge of anode use. But in a few cases the vessels being wooden they did not need anodes. Some older wooden vessels with very few metal components have never had anodes present, so owners tend not to use. 


\subsection{Significance of marine paints as a source of zinc}

The survey indicated that all vessels were using copper based antifouling paints. The antifouling paints are designed for different boat types, speed of travel and conditions (Yebra et al., 2004). The copper based paints will still however contain zinc as pigments and additives to varying levels (Abel, 1999; Yebra et al., 2004; Rees et al., 2014), which will contribute zinc to the estuarine environment. A study by Turner (2010) of paint fragments in recreational UK boatyards showed that some paint chips comprised up to $15 \%$ zinc, and up to $35 \%$ copper. Zinc released from antifouling paints on the Hamble could be relatively large with 3000 boats present, with zinc as high as $15 \%$ present in some of these paints. This source of zinc is however likely to be small compared to the levels released by zinc anodes each year.

\section{Conclusion}

This study has shown that a lack of awareness among some boat owners can often lead to false theories about anode dissolution rates and quicker anode dissolution rates. It is likely that stray currents internal and external to the vessel, along with salinity variations and variations in anode quality are the main reasons for a varied anode dissolution rate.

Calculations form the survey indicate that between 6.95-7.11t/yr of zinc are released annually on the Hamble. The Hamble is currently exceeding zinc EQS levels with concentrations as high as $31 \mu \mathrm{g} / \mathrm{l}$. Anodes are likely to be the largest source of zinc to the Hamble estuary and therefore are likely to be the biggest single contribution to the EQS exceedance.

\section{References}

Abel A.G, (1999) Pigments for paints, paints and surface coatings, theory and practise, $2^{\text {nd }}$ edition, in: Lambourne R and Strivens T.A (eds), Woodhead publishing limited, Cambridge, chapter 3

ACE Group, (2014), Stray electric current safety checklist for marinas and yacht clubs, available online: http://www.acegroup.com/us-en/assets/marine-facilities-insurance-stray-electric-current-tip-sheet.pdf last accessed 17/10/2016

Beane S. J., Comber S. D., Rieuwerts J., and Long P., (2016) Abandoned metal mines and their impact on receiving waters: A case study from Southwest England, Chemosphere, 153: 294-306

Bird P., Comber S.D.W., Gardner M.J. \& Ravenscroft J. (1996) Zinc inputs to coastal waters from sacrificial anodes. The Science of the Total Environment, 181: 257-264

British Marine Federation, (2014) Watersports Participation Survey, available online: http://www.rya.org.uk/SiteCollectionDocuments/sportsdevelopment/Watersports_survey_Market_Review_2013 _Executive_Summary_.pdf last accessed 16/02/2016

BoatU.S, (2016), Types of Marine Corrosion, available online: http://www.boatus.com/boattech/articles/marine-corrosion.asp last accessed 08/04/2016 
Boxall A.B.A., Comber S.D, Conrad A.U., Howcroft J. and Zaman N., (2000) Inputs, monitoring, and fate modelling of Antifouling Biocides in UK estuaries, Marine Pollution Bulletin, 4: 898-905

Briant N., Bancon-Montigny C., Elbaz-Poulichet F., Freydier R., Delpoux S and Cossa D., (2013) Trace elements in the sediments of a large Mediterranean marine (Port Camargue, France): Levels and contamination history, Marine Pollution Bulletin, 73: 78 - 85

Caplat, C., Oral, R., Mahaut, M.L., Mao, A., Barillier, D., Guida, M., Della Rocca, C., and Pagano, G., (2010) Comparative toxicities of aluminum and zinc from sacrificial anodes or from sulfate salt in sea urchin embryos and sperm. Ecotoxicology and Environmental Safety 73: 1138-1143

Cathery, T.M., 2014. An evaluation into the impacts of marinas as a source of zinc concentrations to the Tamar Estuary and Plymouth Sound. Plymouth University Bsc Thesis.

Comber S.D.W., Franklin G., Gardner M.J., Watts C.D., Boxall A.B.A and Howcroft J, (2002) Partitioning of marine antifoulants in the marine environment, The Science of the Total Environment 286: 61-71

Comber S., Gardner M., Jones, V. and Ellor B. (2014) Source Apportionment of Trace Contaminants in Urban Sewer Catchments. Environmental Technology, 36(5), 573-587.

Corrosionpedia, (2015), Stray Current Corrosion, available online: https://www.corrosionpedia.com/definition/1033/stray-current-corrosion last accessed 08/04/2016

DeGiorgia V.G., Thomas E.D., and Lucas K.E., (1988), Scale effects and verification of modeling of ship cathodic protection systems, Engineering Analysis with Boundary Elements, 22: 41-49

Environment Agency, (2016), Water quality data archive, available online: http://environment.data.gov.uk/water-quality/view/landing last accessed 13/10/2016

Gabelle C., Baraud F., Biree L., Gouali S., Hamdoun H., Rousseau C., van Veen E., Leleyter L., (2012), The impact of aluminium sacrificial anodes on the marine environment: A case study, Applied Geochemistry, 27; 2088-2095

Gardner M., Comber S., Scrimshaw M., Cartmell E., Lester J. and Ellor B. (2012), The significance of hazardous chemicals in wastewater treatment works effluents. Science of the Total Environment, 437, 363-372.

Gavrila M., Millet J. P., Mazille H., Marchandise D and Cuntz J. M., (2000), Corrosion behaviour of zincnickel coatings, electrodeposited on steel, Surface and Coatings Technology, 123: 164-172

Genesca J., and Juarez J., (2000) Development and testing of galvanic anodes for cathodic protection, Contributions to science, 1: $331-343$

Harris C., (2008, March) How to conquer corrosion, Sailing Today, P102 - 107

Harrison B., (2015) The extent to which sacrificial anodes act as a zinc source within marinas in Plymouth Sound, BSc Dissertation, University of Plymouth

Jelmert A., and J. H., Van Leeuwen., (2000), Harming local species or preventing the transfer of exotics? Possible negative and positive effects of using zinc anodes for corrosion protection or ballast water tanks, Water Research, 34: 1937-1940 
Mao A., Mahaut M. L., Pineau S., Barillier D. and Caplat C., (2011) Assessment of sacrificial anode impact by aluminium accumulation in mussel Mytilus edulis: A large scale laboratory test, Marine Pollution Bulletin, 62: $2707-2713$

Matthiessen P., Reed J., Johnson M. (1999) Sources and potential effects of copper and zinc concentrations in the estuarine waters of Essex and Suffolk, United Kingdom. Marine Pollution Bulletin, 38: 908-920

Maycock, D., Peters, A., Merrington, G., and Crane, M. (2012) Proposed EQS for Water Framework Directive Annex VIII substances: zinc (For consultation). Water Framework Directive - United Kingdom Technical Advisory Group (WFD-UKTAG). SNIFFER / ENVIRONMENT AGENCY

MGDuff, (2016) Cathodic Protection, available online: http://mgduff.co.uk/ last accessed 08/04/2016

Morgan J. H., (1987) Cathodic Protection, $2^{\text {nd }}$ edition, National Association of Corrosion Engineers, Houston, Texas

Newboatbuilders, (2015), The Connection Between Bonding, Grounding And Lightning, available online: http://newboatbuilders.com/pages/electricity14.html last accessed 08/04/2016

O’Shea F., Spencer K., and Brasington J., (2014) Quantitative assessment of historical coastal landfill contamination using in-situ field portable XRF (FPXRF), Geophysical Research Abstracts, Vol 16, EGU201415584

Pearson H. B. C., Galceran J., Companys E., Braungardt C., Worsfold P,. Puy J., and Comber S., (2016), Absence of Gradients and Nernstian Equilibrium Stripping (AGNES) for the determination of [Zn2p] in estuarine waters, Analytica Chimica Acta, 912: 32-40

Rees A.B., Turner A and Comber S., (2014) Metal contamination of sediment by paint peeling from abandoned boats, with particular reference to lead, The Science of the Total Environment, 494: 313-319

Rousseau C., Baraud F., Leleyter L and Gil O. (2009) Cathodic protection by zinc sacrificial anodes: Impact on marine sediment metallic contamination. Journal of Hazardous Materials, 167: 953-958

Rule K., Comber S., Ross D., Thornton A., Makropoulos C. and Ratui R. (2006) Survey of priority substances entering thirty English wastewater treatment works. Water and Environment Journal, 20, 3, 177-184

Sámano M. L., Pérez M. L., Claramunt I., and García A., Assessment of the zinc diffusion rate in estuarine zones, Marine Pollution Bulletin, 104: 121-128

TB-Training, (2012), Heavy Current Motors, available online: http://www.tb-training.co.uk/MarineE11.html last accessed 13/05/2016

Turner A., and Rees A., (2016), The environmental impacts and health hazards of abandoned boats in estuaries, Regional studies in Marine Science, 6: 75-82

Turner A., Comber S., Rees A.B., Gkiokas D., Solman K., (2015) Metals in boat paint fragments from slipways, repair facilities and abandoned vessels: An evaluation using field portable XRF, Talanta, 131: 372-378

Turner A., (2010) Marine pollution from antifouling paint particles, Marine Pollution Bulletin, 60: 159-171

Wagner P., Little B., Hart K., Ray R., Thomas D., Trzakoma-Paulette P and Lucas K., (1996) Environmental fate of sacrificial ziegraduationnc anodes and influence of a biofilm, International biodeterioration and biodegradation, 151-157 
Wood J (2014) The importance of zinc sacrificial anodes within two Plymouth Marinas, MSc Thesis, Plymouth University

Yebra D.N., Kiil S and Dam-Johansen K., (2004) Antifouling technology-past, present and future steps towards efficient and environmentally friendly antifouling coatings, Progress in Organic Coatings, 50: 75-104

Young D. R., Alexander G.V., and McDermott-Ehrlich D., (1979) Vessel-related contamination of Southern

California Harbours by copper and other metals, Marine Pollution Bulletin, 10: 50-56 


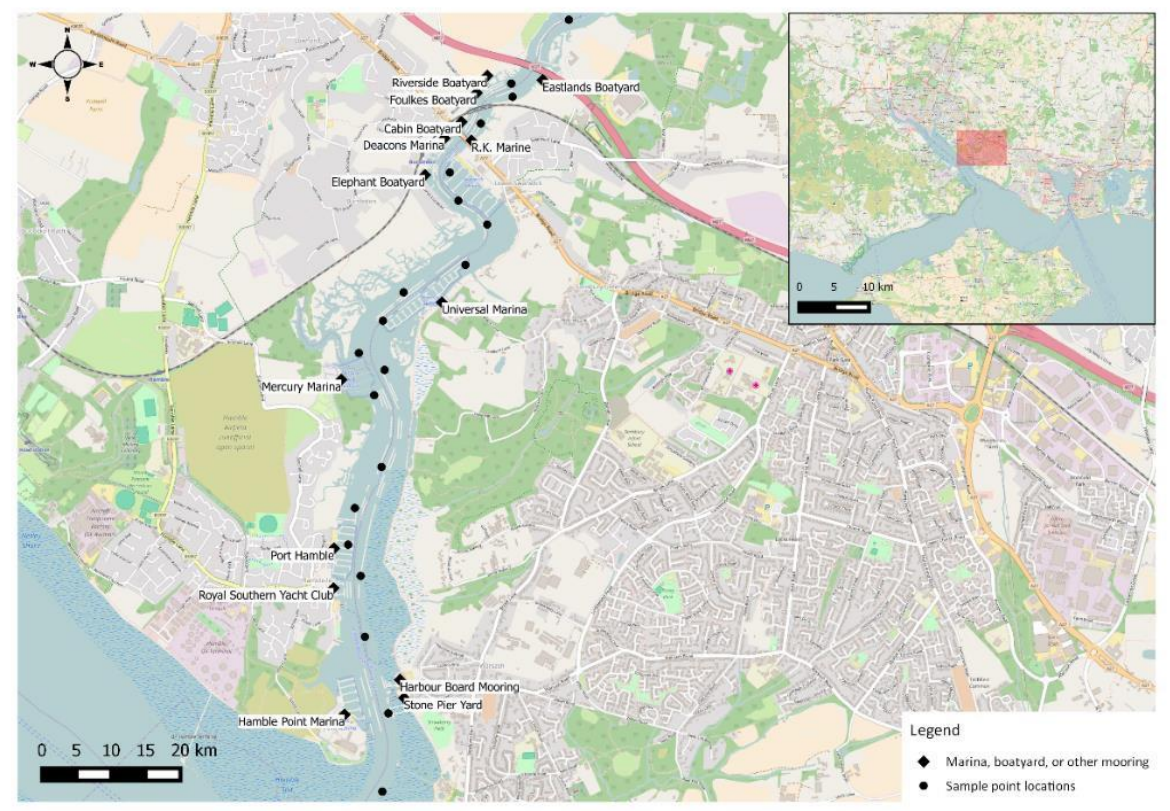

Fig 1 Map showing dissolved zinc sample sites and marinas within the Hamble. The two control sites at Netley (Southampton Water) and Lee on Solent are off the main map 


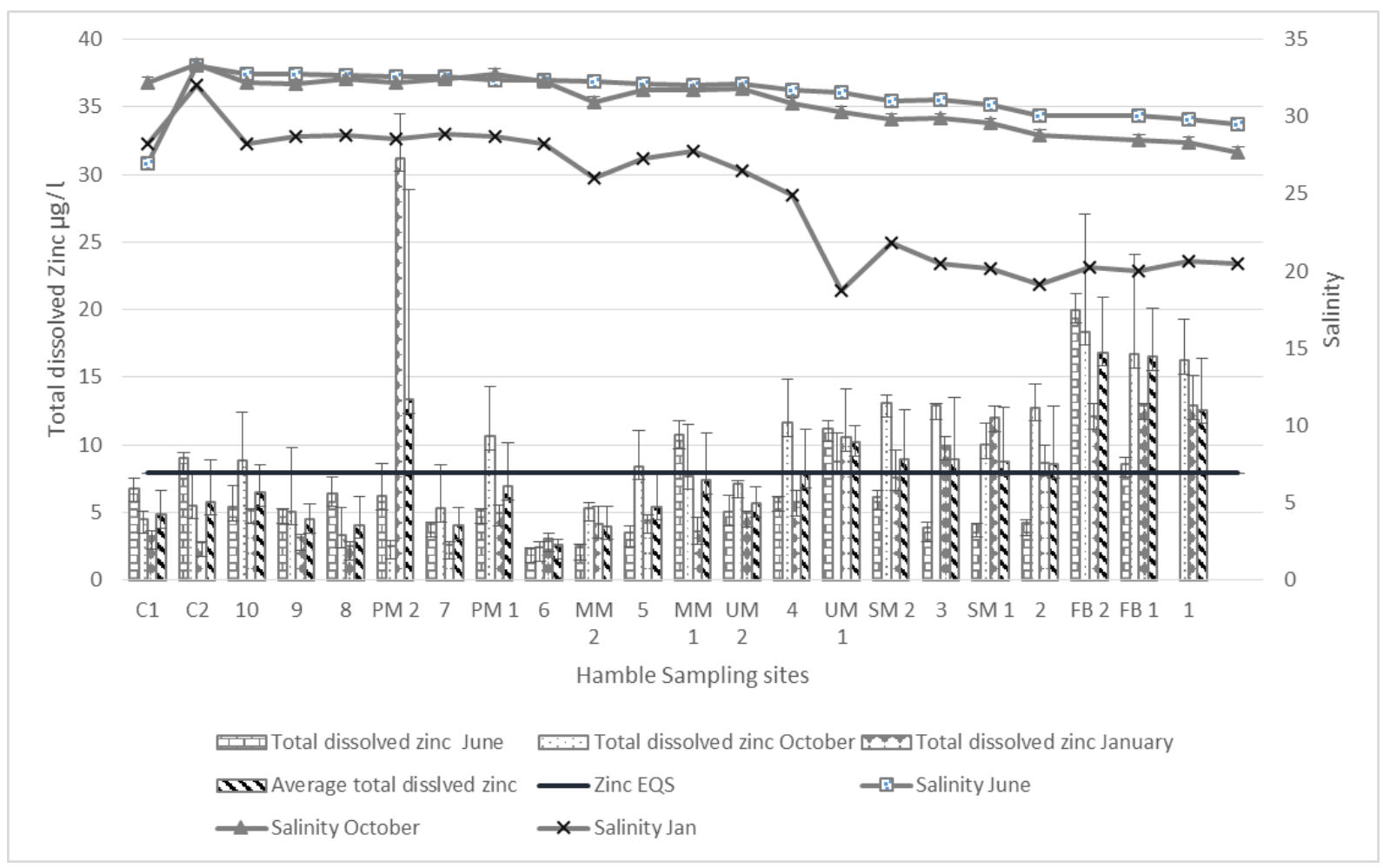

Fig 2 Average total dissolved zinc levels in the Hamble estuary, compared to EQS levels. The salinity plots show the salinity varies from 20-28 in January and 27-32 in June and October. Error bars denote the standard deviation between samples. Site codes 1 - 10 run from the mouth of the Hamble (10) to above Bursledon where boat moorings stop (1), PM is either side of Port Hamble Marina, MM Mercury, UM Universal Marina, SM Swanwick Marina and FB Foulkes Boatyard. C1 control site Netley and C2 control site Lee on Solent, Southampton Water

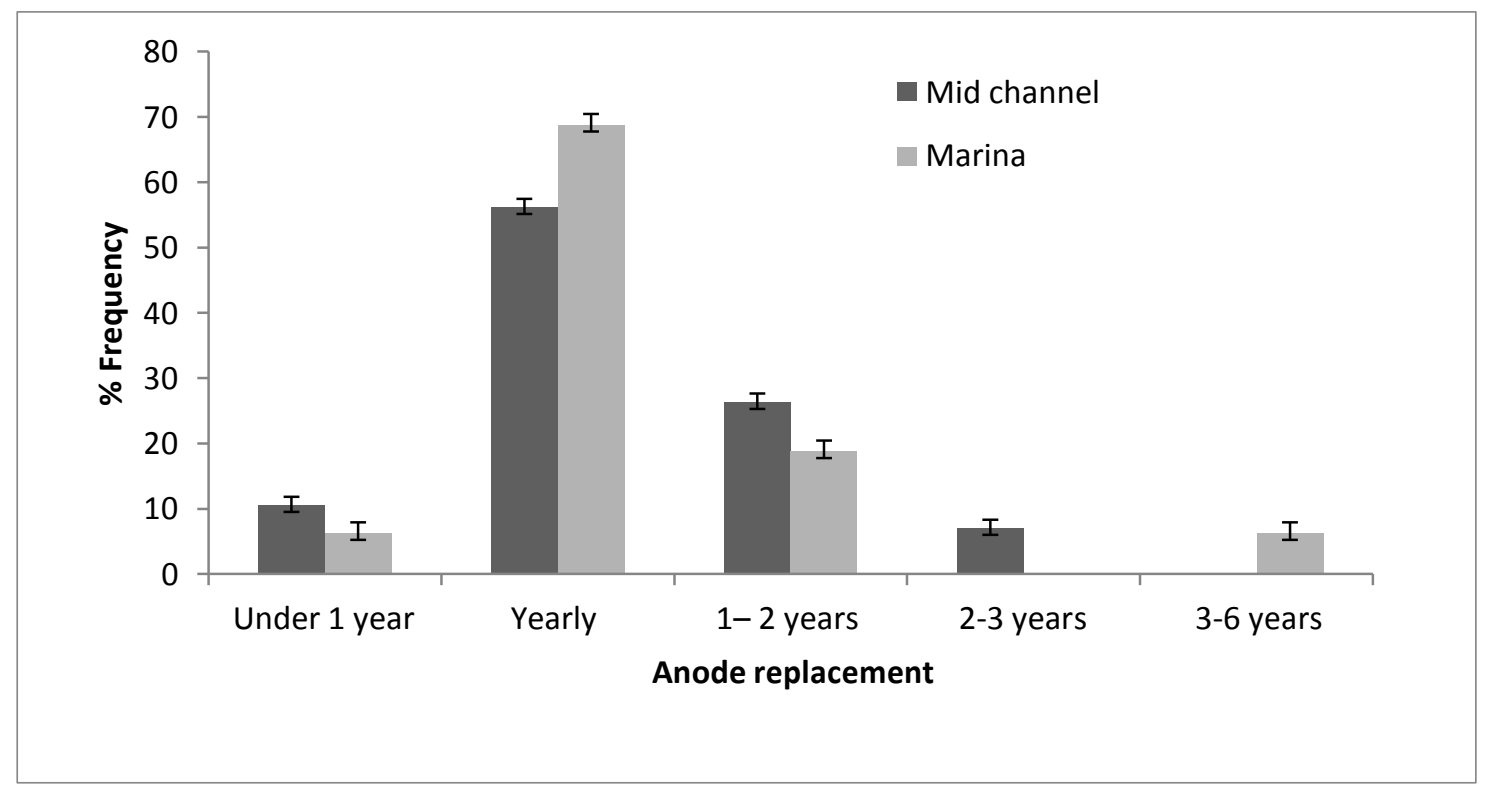

Fig 3 Percentage frequency of anode replacement based on mooring location. Error bars based on 95 percentile values 


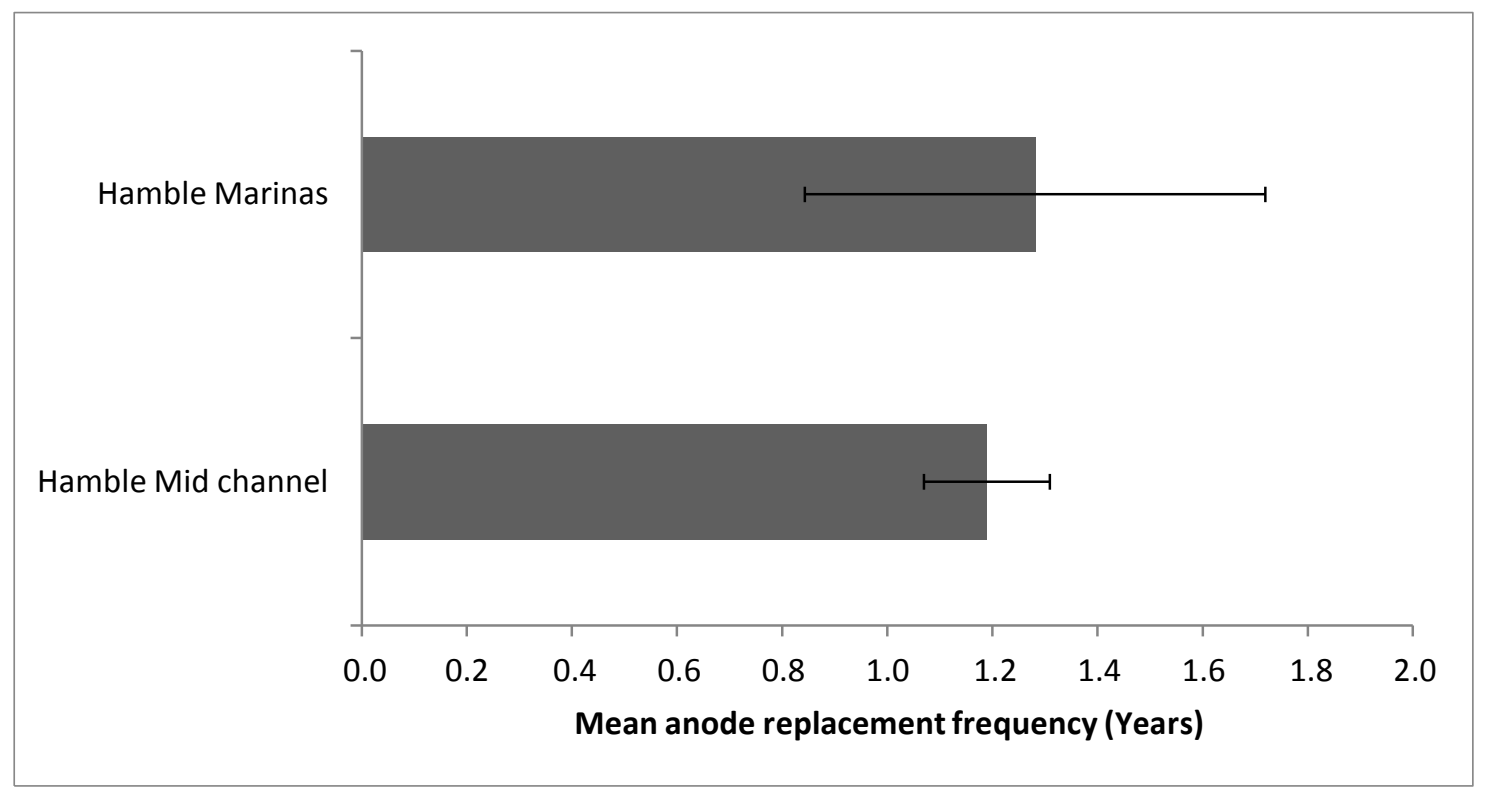

Fig 4 Mean replecament using midpoint frequncy replcement in years. Error bars denote 95 percentile confiidnce intervals

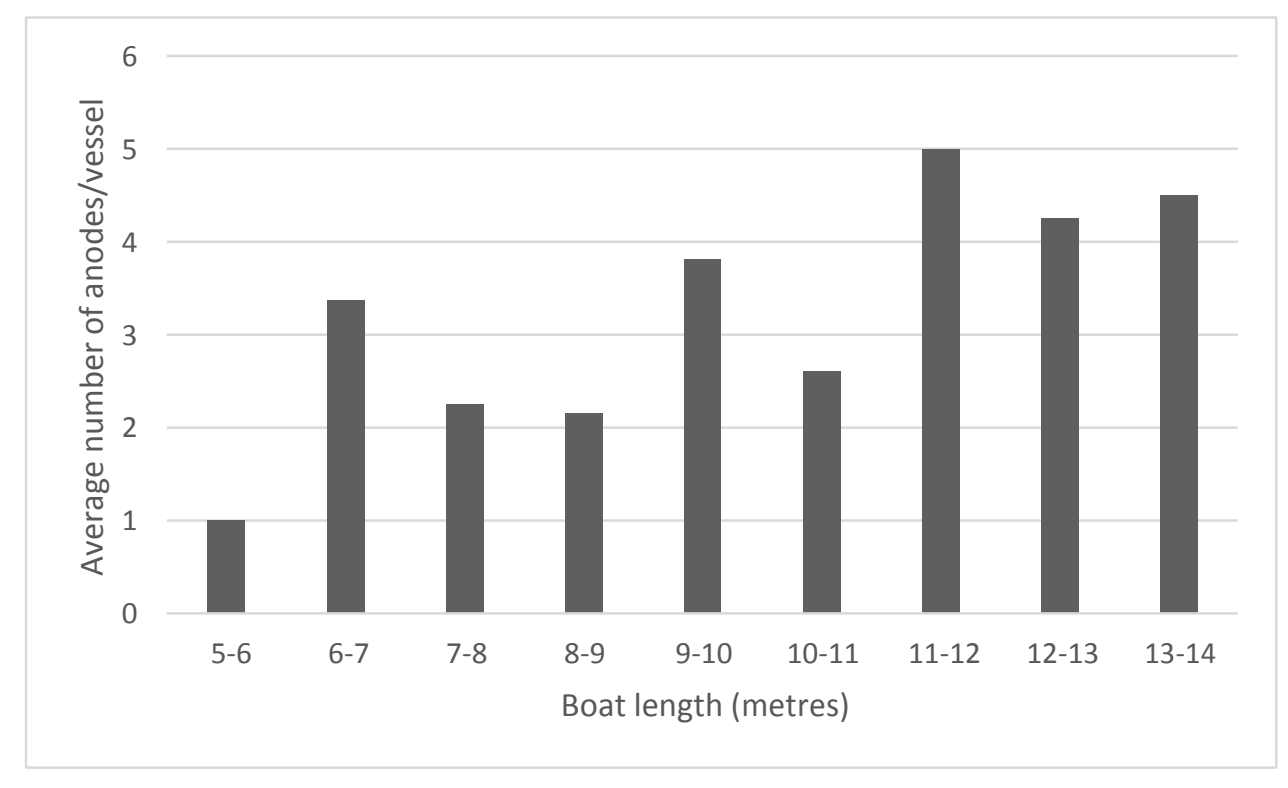

Fig 5 Boat length versus average number of anodes used 


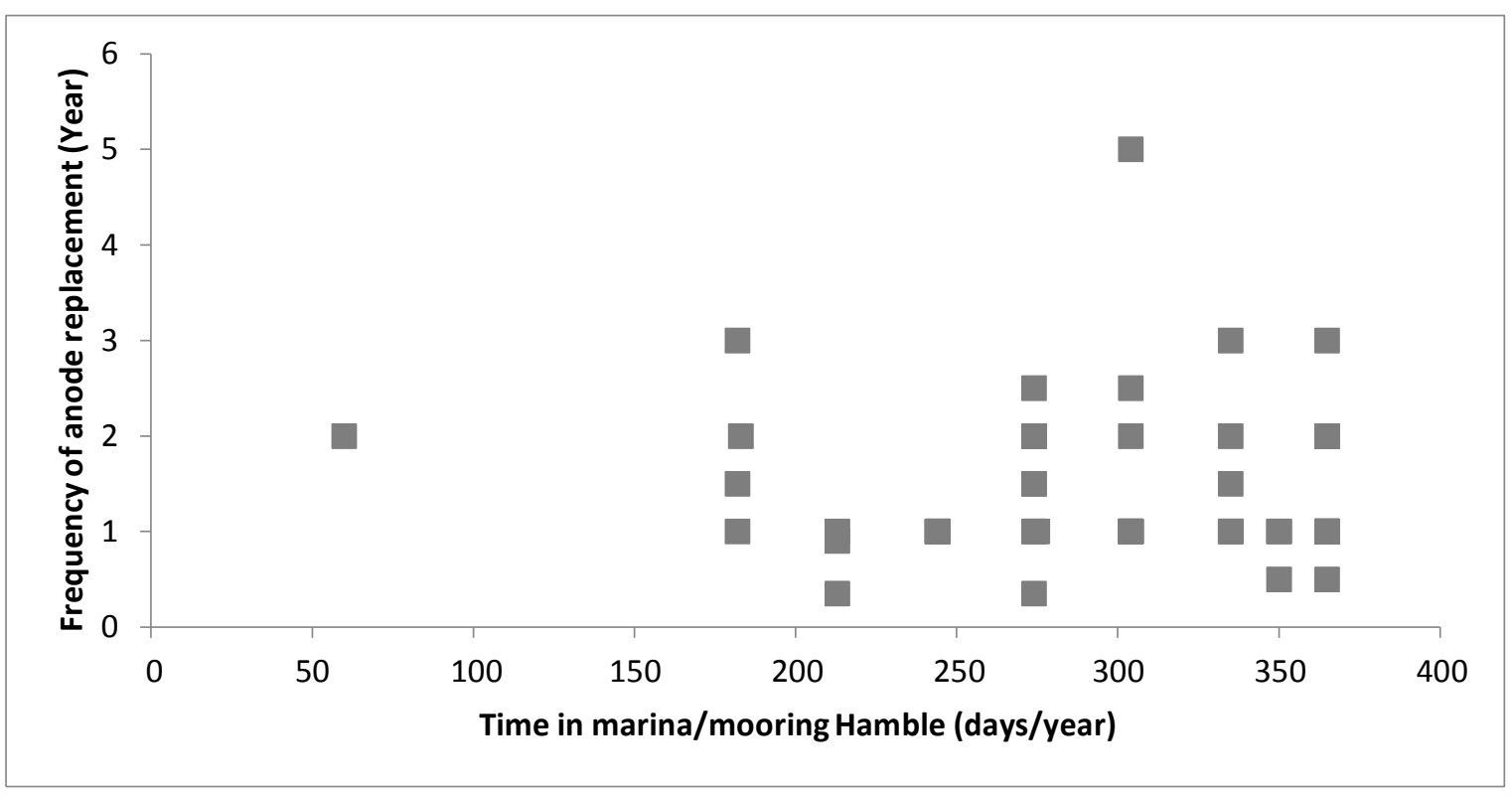

Fig 6 Time in marina versus frequency of anode replacement

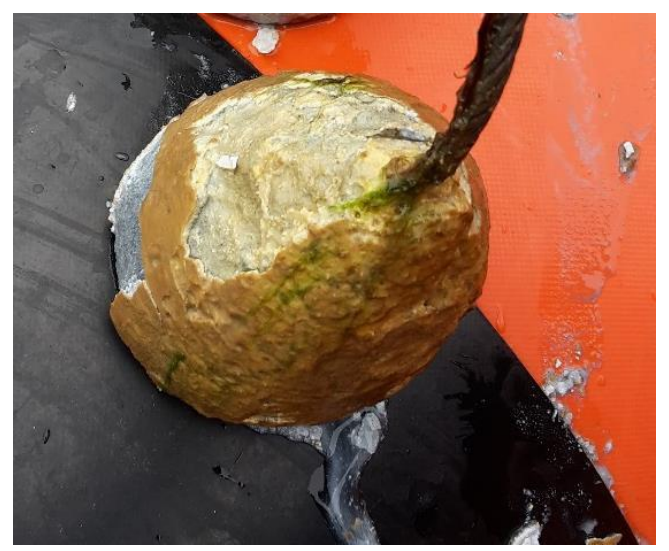

Fig 7 Anodes form a layer of zinc hydroxide and calcium if they dry out or are exposed to freshwater or brackish conditions, thus effecting corrosion rates 


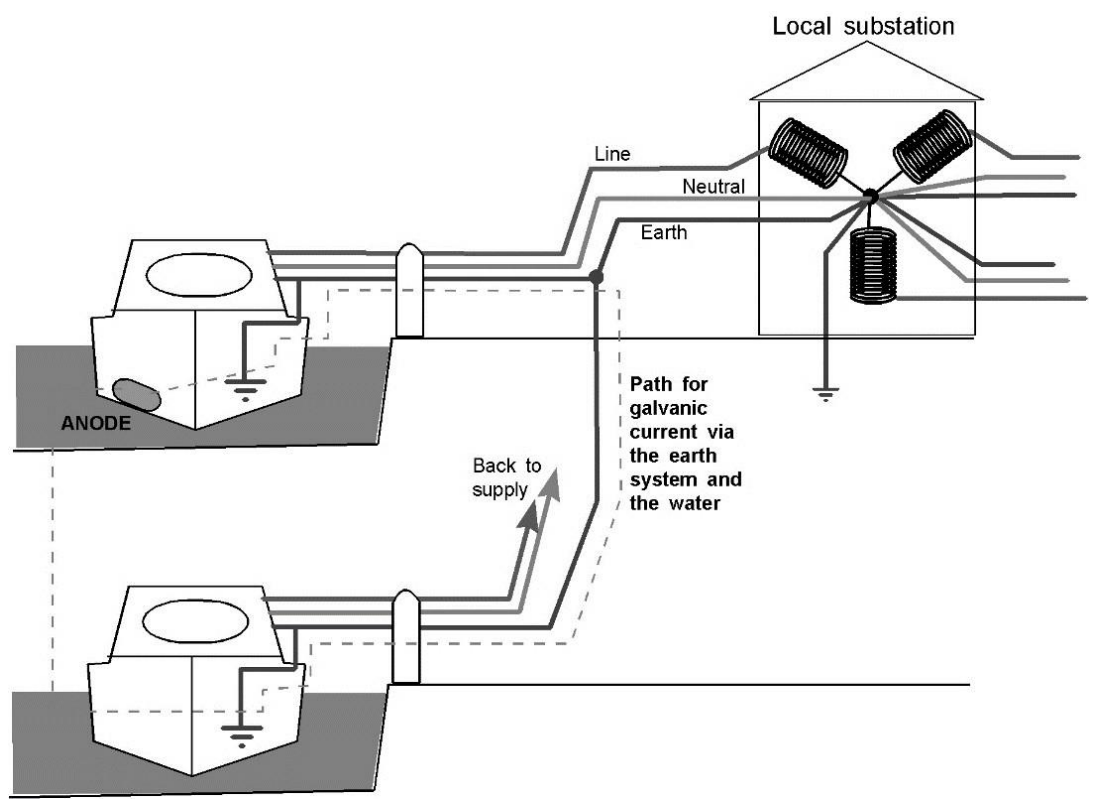

Fig 8 Stray current and galvanic corrosion can occur when vessels are connected through a common earth wire or with a wiring fault on another vessel. This can lead to an accelerated anode dissolution rate (TB-Training, 2012) 